\title{
An Epidemiologic Study of Dental Caries in Preschool Children in the United States by Race and Socioeconomic Level
}

\author{
PETER F. INFANTE and ALBERT L. RUSSELL \\ Center for Human Growth and Development and School of Public Health, \\ University of Michigan, Ann Arbor, Michigan 48104, USA
}

The prevalence of dental caries in 1,155 white and black preschool children was studied in the United States in 1969 and 1970. The results demonstrated that white children of the lower socioeconomic level had a significantly greater prevalence of dental caries than middle class white children, but a significantly lower prevalence than black children, most of whom represented the lower social class.

Although the literature contains many reports concerning the prevalence of dental caries in schoolchildren and adults, there is a paucity of information about the prevalence of dental caries in preschool aged children. Estimates of proportions of children with one or more def teeth have ranged from 18 to $34 \%$ for the 2-year-old child to $78 \%$ for the 5-year-old child.1-3 When black and white school aged children are compared, a higher caries prevalence has ordinarily been reported for blacks.4-7 Associations between caries experience and socioeconomic status have been contradictory. ${ }^{3,4}$, 8-12 Most findings have been applicable only to a finite population group in a specific locality. Therefore, a study of dental caries in preschool children drawn from a wider base seemed necessary. Such a study was carried out with a quasi-random sample in the years 1969 and 1970 .

\section{Materials and Methods}

A survey of the nutritional status of preschool children in the United States was

This study was supported by contract MC-R-39005006-0 from Maternal and Child Health Services, Department of Health, Education and Welfare and by Grant No. 5T01-DE-00287-05 from the National Institutes of Health, Bethesda, Md.

Received for publication April 6, 1973. conducted in 1969 and 1970. Seventy-four sample areas were chosen. ${ }^{13}$ These areas were further subdivided into sampling units. Dental examinations were carried out in 60 to $80 \%$ of these sampling units. The sample included children from about 36 states.

One thousand one hundred and fifty-five white and black children between the ages of 1 and 6 years were examined by one dentist (P.F.I.). A mouth mirror, dental explorer, and portable dental light were used to detect lesions. The children were seated in a portable dental chair or held on the lap of an adult, usually the mother. Dental caries was expressed in a modification of the def index. It was possible to ascertain from the mother the reason for the relatively few missing deciduous teeth. If she indicated that a carious lesion had been the reason for a tooth loss, the tooth was categorized as " $\mathrm{e}$ " (extracted) and was considered a tooth with caries experience. Comparisons were based on the total number of deciduous teeth and deciduous tooth surfaces with caries experience as well as presence or absence of caries. Only obvious lesions in which soft dentin could be detected were considered carious lesions. Deep pits and fissures that were sound were not recorded as carious. No oral radiographs were made. An assistant recorded the findings.

In addition to the dental examination, each child was rated according to socioeconomic status. The method used was the Warner Index Stratification Characteristic, which is based on the ratings of occupation, source of income, dwelling type, and dwelling area. ${ }^{14}$

\section{Results}

The numbers of deciduous teeth and surfaces with caries experience were determined 
TABLE 1

mean Total Number of def Teeth and Mean Defective Tooth SuRfaces IN WHITE Boys AND GrRLS

(United States, 1969-1970)

\begin{tabular}{|c|c|c|c|c|c|c|c|c|}
\hline \multirow[b]{2}{*}{$\begin{array}{l}\text { Age } \\
(\mathbf{y r})\end{array}$} & \multicolumn{4}{|c|}{ Boys } & \multicolumn{4}{|c|}{ Girls } \\
\hline & $\begin{array}{c}\text { Mean } \\
\text { Age }\end{array}$ & $\mathbf{N}$ & $\begin{array}{l}\text { Mean } \\
\text { Teeth }\end{array}$ & $\begin{array}{c}\text { Mean } \\
\text { Surfaces }\end{array}$ & $\begin{array}{c}\text { Mean } \\
\text { Age }\end{array}$ & $\mathbf{N}$ & $\begin{array}{l}\text { Mean } \\
\text { Teeth }\end{array}$ & $\begin{array}{c}\text { Mean } \\
\text { Surfaces }\end{array}$ \\
\hline 1 & 1.49 & 86 & 0.02 & 0.02 & 1.48 & 73 & 0.26 & 0.26 \\
\hline 2 & 2.54 & 80 & 0.25 & 0.25 & 2.47 & 106 & 0.24 & 0.43 \\
\hline 3 & 3.53 & 97 & 1.94 & 3.00 & 3.55 & 103 & 1.32 & 1.64 \\
\hline 4 & 4.52 & 102 & 2.75 & 3.69 & 4.52 & 105 & 2.38 & 3.39 \\
\hline 5 & 5.48 & 102 & 3.69 & 5.64 & 5.48 & 103 & 3.78 & 5.99 \\
\hline
\end{tabular}

for each child. Mean numbers were computed separately for white children of both sexes by one-year age intervals. The findings are shown in Table 1. Since sex differences in dental caries experience were not apparent, data for boys and girls were combined and white children were then compared with black children for the mean total number of defective teeth and surfaces by one-year age intervals (Table 2). With the exception of the first age interval, black children had more affected teeth and surfaces than did white children in each age-group comparison. The standard deviations for the mean total number of affected teeth were usually greater than the mean; the confidence intervals were asymmetrical. For this reason, differences in caries experience between groups were analyzed by percentages of children with one or more decayed teeth vs those who were cariesfree. Table 3 shows that black children had a higher prevalence of dental caries at each age level. The differences in caries prevalence between all black and white preschool children were highly significant.
White children of the middle and lower socioeconomic levels were then compared for prevalence of dental caries by age and sex. For all comparisons, white children of the middle class in both sex groups had a higher percentage of cariesfree individuals than did children of the lower class (Table 4). With age and sex groups pooled, the difference in caries prevalence was highly significant.

To determine if the racial differences in the prevalence of dental caries could be attributed to factors related solely to socioeconomic status, the black children - (almost all of whom represented the lower socioeconomic level by the Warner rank ${ }^{14}$ ), were compared with the white lower class children. This comparison indicated that black children had a higher caries attack rate than white children of the lower socioeconomic level. The difference in the prevalence of dental caries between all black children and white children of the lower socioeconomic level, ages 1 to 6 combined, are shown in Table 5. The results indicate that lower class white children had a significantly lower caries attack than did black children.

TABLE 2

Mean Total Number of def Teeth and Mean Defective Tooth Surfaces in Black aNd White Childeren

(boys and girls combined, United States, 1969-1970)

\begin{tabular}{|c|c|c|c|c|c|c|c|c|c|c|}
\hline \multirow[b]{2}{*}{$\begin{array}{l}\text { Age } \\
(\mathrm{yr})\end{array}$} & \multicolumn{5}{|c|}{ White Children } & \multicolumn{5}{|c|}{ Black Children } \\
\hline & $\begin{array}{c}\text { Mean } \\
\text { Age }\end{array}$ & $\mathbf{N}$ & $\begin{array}{l}\text { Mean } \\
\text { Teeth }\end{array}$ & $\mathrm{SD}^{*}$ & $\begin{array}{c}\text { Mean } \\
\text { Surfaces }\end{array}$ & $\begin{array}{c}\text { Mean } \\
\text { Age }\end{array}$ & $\mathbf{N}$ & $\begin{array}{l}\text { Mean } \\
\text { Teeth }\end{array}$ & SD* & $\begin{array}{c}\text { Mean } \\
\text { Surfaces }\end{array}$ \\
\hline 1 & 1.49 & 159 & 0.13 & 1.16 & 0.13 & 1.47 & 38 & 0.03 & 0.16 & 0.03 \\
\hline 2 & 2.50 & 186 & 0.24 & 1.04 & 0.35 & 2.50 & 32 & 1.50 & 3.22 & 1.97 \\
\hline 3 & 3.54 & 200 & 1.62 & 2.93 & 2.30 & 3.48 & 41 & 2.61 & 3.04 & 8.49 \\
\hline 4 & 4.52 & 207 & 2.57 & 3.64 & 3.54 & 4.52 & 45 & 3.84 & 3.74 & 5.56 \\
\hline 5 & 5.48 & 205 & 3.97 & 3.73 & 5.81 & 5.55 & 42 & 5.12 & 4.84 & 8.52 \\
\hline
\end{tabular}

- SD, standard deviation. 
TABLE 3

Prevalence of Dental Caries in 1,155 White and Black Children

\begin{tabular}{lcccccc}
\hline \hline \multirow{2}{*}{$\begin{array}{l}\text { Age } \\
(\mathbf{y r})\end{array}$} & \multicolumn{2}{c}{ White Children } & & \multicolumn{3}{c}{ Black Children } \\
\cline { 2 - 5 } & $\mathrm{N}$ & \% Caries free & $\mathrm{N}$ & \% Caries free & $\chi^{*}$ \\
\hline 1 & 159 & 98.5 & 38 & 98.4 & \\
2 & 186 & 88.7 & 32 & 65.6 & \\
3 & 200 & 59.5 & 41 & 31.7 & \\
4 & 207 & 45.9 & 45 & 24.4 & \\
5 & 205 & 29.3 & 42 & 26.2 & \\
\hline All ages & 957 & 62.1 & 198 & 47.0 & 15.56* \\
\hline
\end{tabular}

- $P<0.001$, chi-square with one degree of freedom.

TABLE 4

Prevalence of Dental Caries in 957 White Boys and Girls by Age AND Socioeconomic Status

\begin{tabular}{|c|c|c|c|c|c|c|}
\hline \multirow[b]{2}{*}{ Group } & \multirow{2}{*}{$\begin{array}{l}\text { Age } \\
(\mathbf{y r})\end{array}$} & \multicolumn{2}{|c|}{ Middle Class } & \multicolumn{3}{|c|}{ Lower Class } \\
\hline & & $\mathrm{N}$ & $\%$ Caries free & $\mathrm{N}$ & $\%$ Caries free & $\chi^{2}$ \\
\hline \multirow[t]{6}{*}{ Boys } & 1 & 44 & 100.0 & 42 & 97.6 & \\
\hline & 2 & 41 & 95.1 & 39 & 76.9 & \\
\hline & 3 & 50 & 64.0 & 47 & 46.8 & \\
\hline & 4 & 45 & 55.6 & 57 & 36.8 & \\
\hline & 5 & 50 & 30.0 & 52 & 28.8 & \\
\hline & All ages & 230 & 67.4 & 237 & 54.4 & $8.19 *$ \\
\hline \multirow[t]{6}{*}{ Girls } & 1 & 34 & 97.1 & 39 & 94.9 & \\
\hline & 2 & 60 & 91.7 & 46 & 89.1 & \\
\hline & 3 & 44 & 68.2 & 59 & 59.3 & \\
\hline & 4 & 55 & 49.1 & 50 & 44.0 & \\
\hline & 5 & 55 & 32.7 & 48 & 25.0 & \\
\hline & All ages & 248 & 65.7 & 242 & 60.7 & 1.31 \\
\hline Boys and & 1 & 78 & 98.7 & 81 & 96.3 & \\
\hline Girls & 2 & 101 & 93.1 & 85 & 83.5 & \\
\hline \multirow[t]{4}{*}{ combined } & 3 & 94 & 66.0 & 106 & 53.8 & \\
\hline & 4 & 100 & 48.0 & 107 & 40.2 & \\
\hline & 5 & 105 & 31.4 & 100 & 27.0 & \\
\hline & All ages & 478 & 66.5 & 479 & 57.6 & $8.05 *$ \\
\hline
\end{tabular}

- $P<0.01$, chi-square with one degree of freedom.

TABLE 5

Differences in Prevalence of Dental Caries Between All Black

Children and White Lower Cllass Children (boys and girls combined), Ages I to 6 Years Combined

\begin{tabular}{|c|c|c|c|c|c|c|}
\hline \multirow[b]{2}{*}{ Group } & \multirow[b]{2}{*}{$N$} & \multicolumn{2}{|c|}{$\begin{array}{l}\text { One or More } \\
\text { Carious Teeth }\end{array}$} & \multicolumn{2}{|c|}{ Caries free } & \multirow[b]{2}{*}{$x^{2}$} \\
\hline & & $N$ & $\%$ & $\mathbf{N}$ & $\%$ & \\
\hline $\begin{array}{l}\text { White lower } \\
\text { class children }\end{array}$ & 479 & 203 & 42.4 & 276 & 57.6 & $6.39 *$ \\
\hline $\begin{array}{l}\text { All black } \\
\text { children }\end{array}$ & 198 & 105 & 53.0 & 93 & 47.0 & \\
\hline
\end{tabular}




\section{Discussion}

These findings are not compatible with commonly expressed beliefs that black children and children of the lower socioeconomic groups have more favorable caries experience than white children or children in the higher socioeconomic strata. Because children of both racial groups were chosen from urban and rural areas alike, the observed racial differences in dental caries experience are not considered to be the result of urban-rural differences. Although information about the length of exposure to a fluoridated water supply was not available, the random selection procedures used make it unlikely that this variable could account for the racial differences observed.

Although earlier studies $\mathbf{4}, \mathbf{6}$ show that black children have lower caries experience, other more recent studies ${ }^{5,7}$ have found little or no difference in caries experience in the permanent teeth of black and white children. Comparison of the present results with those reported by Summers ${ }^{5}$ for 5-year-old children of Detroit before fluoridation suggests that black children of this study have a much greater caries incidence; white chil. dren have about the same. Such findings suggests that there may be a secular trend of increased caries experience for black children. The higher caries prevalence among children of the lower socioeconomic level is compatible with some previous reports.

\section{Conclusions}

The prevalence and severity of dental caries in the deciduous dentition of preschool children are significantly greater in black children than in white children. White children from the lower socioeconomic level have a significantly greater prevalence of dental caries than white children from the middle socioeconomic level, but a lower prevalence than black children. No sex differences in caries experience were observed.

The authors thank G. Owen, W. Zacherl, and members of the field team of the national survey for their help in securing the data.

\section{References}

1. HeNNON, D.K.; STOOKEY, G.K.; and MuHLER, J.C.: Prevalence and Distribution of Den- tal Caries in Preschool Children, JADA 79: 1405-1414, 1969.

2. Savara, B.S., and Suher, J.: Incidence of Dental Caries in Children I to 6 Years of Age, $J$ Dent Res 33: 808-823, 1954.

3. Wisan, J.M.; Lavele, M.; and Colwell, F.H.: Dental Survey of Philadelphia Preschool Children by Income, Age and Treatment Status, JADA 55: 1-10, 1967.

4. SzweJDA, L.F.: Dental Caries Experience by Race and Socioeconomic Level After Eleven Years of Water Fluoridation in Charlotte, North Carolina, Public Health Dent 22: 9198, 1962.

5. Summers, C.J.: Dental Needs and Prevalence of Dental Caries in Wayne County Grade School Children, J Mich Dent Assoc 52: 127 $135,1970$.

6. Johnson, E.S.; KeLLY, J.E.; and VAN KiRK, L.E.: Selected Dental Findings in Adults by Age, Race, and Sex, United States-1960-62, USPHS, National Center for Health Statistics, Series 11, No. 7, Washington, DC: Government Printing Office, November 1965.

7. Bagramian, R.A., and Russell, A.L.: An Epidemiologic Study of Dental Caries in Race and Geographic Area, $J$ Dent Res 50: 1553-1556, 1971.

8. Hagan, J.L.: Dental Caries Prevalence and and Tooth Mortality Study of 24,092 Georgia Children in Twelve Communities, Public Health Rep 62: 1757-1767, 1947.

9. Sradt, Z.M.; Blum, H.L.; Kent, G.W.; Fletcher, E.; Keyes, G.; and Frost, L.A.: Socio-economic Status and Dental Caries Experience of 3,911 Five-Year-Old Natives of Contra Costa County, California, Public Health Dent 27: 2-6, 1967.

10. SzwejDa, L.F.: Observed Differences of Total Caries Experience Among White Children of Various Socio-economic Groups, Public Health Dent 20: 59-66, 1960.

11. Castaldi, G.R.; Quigley, W.; and Zackeral, W.: Fluoridation, Dental Health, and SocioEconomic Level, $J$ Dent Res 40: 727, 1961 (abstract) .

12. Savara, B.S., and Suher, J.: Dental Caries in Children One to Six Years of Age as Related to Socio-Economic Level, Food Habits, and Toothbrushing, $J$ Dent Res 34: 870$875,1955$.

13. Krsh, L., and Hess, I.: The Survey Research Center's National Sample for Dwellings, Institute for Social Research, Publication No. 2315, Ann Arbor, University of Michigan, 1965.

14. Warner, W.L.: Social Class in America, New York: Harper and Row, 1960. 